effect, indicating, thereby, also that the duration of the state of excitement and the intensity of the excitement are greater than in the other diseases.

These results are quite different from those obtained by the use of restraint without hydrotherapy. It is unnecessary here to recall the remarkable improvement in the condition of exeited patients produced by the modern methods of non-restraint, in which diversion and occupation take the place of padded cells, straitjackets, and strong rooms.

More to the point, perhaps, will be the startling figures obtained in a study of the treatment of delirium by hydrotherapy at the Psychopathic Hospital, Boston, compared to the results of the older methods of restraint and depressing drugs without hydrotherapy, employed at general hospitals. The mortality in general hospitals averages 26 per cent., the mortality in the Psychopathic Hospital, under hydrotherapy, more especially packs, averages 0 per cent. ${ }^{3}$

On account of these facts, it is safe to infer that hydrotherapy, whether applied in the form of prolonged baths or as wet packs, has a therapeutic effect, which is not to be obtained by mere immobilization of the patient or by restraint.

The question of restraint, of course, is an important one for administrative reasons. However, these figures prove that the wet packs not only cannot be condemned for reasons of cruelty, but that they are the most potent means of obtaining rest for a maniacal patient. The wet pack has been used at the Psychopathic Hospital consistently as an auxiliary to the prolonged bath, and bears the same relation to the latter that hypodermic medication bears to medication per os. A patient who cannot or will not swallow medicine may still derive the benefits from the drugs when they are administered subcutaneously. A subcutaneous injection of heart stimulant, for instance, may be applied against the wishes of an insane person. It may be applied in cases of unconsciousness and so forth. It offers a means of applying a therapeutic agent without the coöperation or even the consent of the patient. In the same way, the pack may be used to administer the heneficial effects of hydrotherapy, and in particular, of the prolonged bath, to patients who are so restless or excited that they cannot be induced to submit to the prolonged bath.

\begin{tabular}{|c|c|c|c|c|}
\hline Duanosis & $\begin{array}{l}\text { No. oF } \\
\text { CANES }\end{array}$ & $\begin{array}{l}\text { No. OF } \\
\text { PACKS }\end{array}$ & $\begin{array}{l}\text { Quierina } \\
\text { FrFect }\end{array}$ & $\begin{array}{l}\text { NoN } \\
\text { QUIETING } \\
\text { EFPEC' }\end{array}$ \\
\hline Dementia Praecox.... & 82 & 217 & 143 & 74 \\
\hline Manic-Depressive I $n$ & & & & \\
\hline $\begin{array}{l}\text { sanity : } \\
\text { Manic } \ldots \ldots \ldots\end{array}$ & 71 & 336 & 130 & $20 x)$ \\
\hline Depressed $\ldots \ldots$ & 8 & 26 & 8 & 18 \\
\hline Alcoholic Hallucinosi. & 1520 & 40 & 28 & 12 \\
\hline Delirium Tremens... & . 20 & 34 & 21 & 13 \\
\hline Alcoholism $\ldots \ldots \ldots$ & .5 & 7 & ti & 1 \\
\hline Organic Dementia... & 4 & 14 & 7 & 7 \\
\hline Senile Dementia..... & 4 & 6 & 5 & 1 \\
\hline Involution $\ldots \ldots \ldots$ & 3 & 4 & 4 & 0 \\
\hline Epilepsy $\ldots \ldots \ldots \ldots$ & 8 & 14 & 12 & 2 \\
\hline Paraphrenia ........ & 2 & 3 & 3 & 0 \\
\hline
\end{tabular}

HIBHOGLAP'HY.

Remarks on Hydrotherapy. (A Note on the Influence of Hydro. therapy on the Red Cell Blood Court in the Insane). H. M. Adler and B. H. Ragle, Boston Medical and Suroical Journal, Sept. 18, 1913.

Kraepelin: Psychiatrie, Ed. 8, Vol. I, p. 578.

The Treatment of the Deliria in General Hospitals and in Ilospitals for the Insane. Donald Gregr, M.D. Psychopathic Hospital Contribution, 1913, No. 10.

\section{JOHN CLARENCE CUTTER, M.D.}

\section{By Sarah H. Powers.}

Dr. John Clarence Cutter was born in Warren, Massachusetts, July 10, 1851, eldest son of Dr. Calvin Cutter, the author of Cutter's Physiology, and Eunice Powers, a woman of the old school of culture.

After he received his education in the public schools of Warren, he entered the Agricultural College at Amherst, from which he was graduated in 1872. He spent a year in J. B. Lippincott's publishing house, then attended Dartmouth Medical School for two years, from which he went to Harvard Medical School, where he was graduated in 1877. Before he received his diploma he had gained the post of house surgeon in the City Hospital.

In 1878 he went to Japan to accept the position of professor of physiology and comparative anatomy in the College of Agriculture, Sapporo, Island of Yezo. When he arrived at Tokio he was made the consulting physician of the Imperial Colonial Department. His first contract with the government was for two years. He was liked so well, that he renewed it from time to time until he had been with the college nine years. At his mother's urgent request, he did not renew his contract in 1887 , but came home through Europe. Before leaving Japan, the Emperor conferred on him the Order of the Rising Sun, Meiji, fourth class.

While in Japan, Dr.'Cutter wrote several physiologies which were translated into Japanese. After his return home, he revised his father's books, which had been translated into thirteen different languages and printed in raised letters for the blind.

In 1888 he went to Berlin and Vienna to study skin diseases. In the fall of 1890 he opened an office in Worcester. Soon after coming to Worcester, while assisting another physician in performing an operation, he contracted blood poison from which he never fully recovered.

Dr. Cutter came from a long line of famous ancestors on his mother's side, born in Warren. In Colonial times, they were foremost in the life of the town; they fought in the Indian Wars, in the Revolution, in the War of 1812, and the Civil War.

Dr. Cutter "was energetic and possessed of forcible character. He had the courage of his convictions, and his fearlessness counted much 


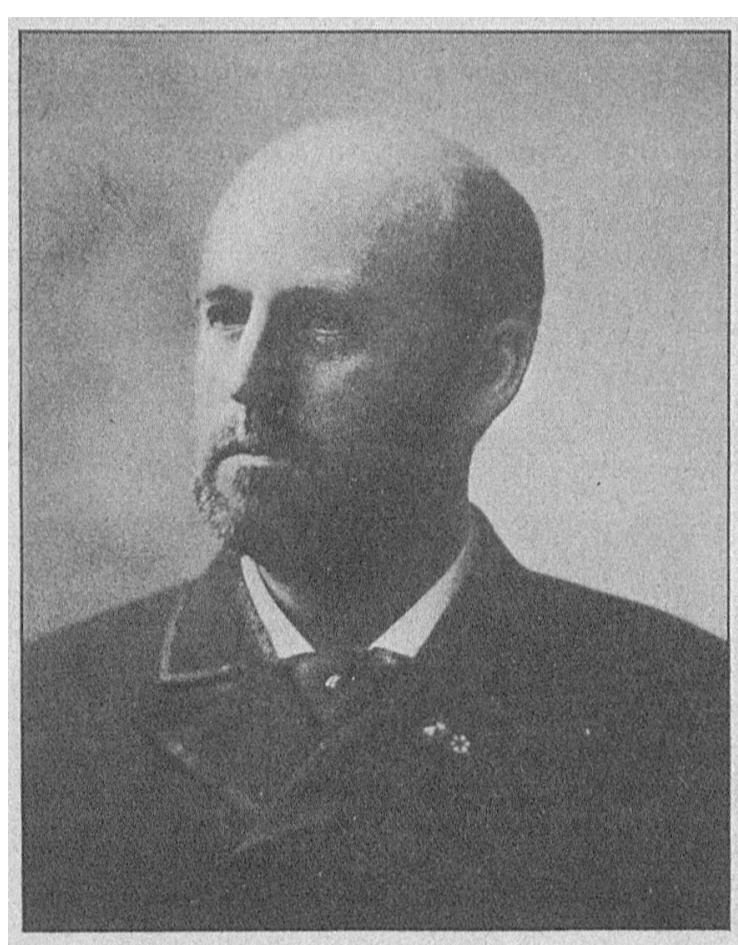

John (. Cu't'kir, M.I), Sapporo, Japan, 1884.

in accounting for the honors thrust upon him abroad."

One of his peculiarities was that he never turned the conversation on himself, so that very lew knew the facts of his career. 'To a few intimate friends only would he allude to his travels or life in the Orient. After his mother's death in 1893, he gave up his practice and spent the following winter in Mexico and California. In fact (for the next three years) he traveled most of the time in the United States. He said he had been in every state and every territory but one in the Union. He was very fond of travel and said a train of cars had a peculiar fascination for him. In 1897 he received a shock, which left him with partial paralysis. It also affected his eyesight and memory. Several winters during his illness he spent with Dr. Robert I. Edes, in Boston. Although an invalid, he retained his interest in affairs of the world. He was particularly anxious to have us read to him the happenings in the medical world.

$\mathrm{He}$ did not remember what took place from day to day, but still could talk intelligently on most subjects. It seemed sad to see him, with a bright outlook and much good work planned, in such a condition, stricken in the prime of life. He was very patient, and never complained. When anyone alluded to his trouble, he would reply, "It is all right, it was to be. It had better be I than the other man, who has a wife and children. I have neither." He died February 2, 1909, of cerebral hemorrhage, after twelve years' illness.
He was straight and honest in all his dealings and wished others to be the same.

When his father died, he left debts to the amount of several thousands, all of which the doctor, with his mother's help, paid dollar for dollar, also the interest. When asked by one of his classmates why he did it, he replied, "I do not care to have people say, 'Oh! he got his education-and his father's debts not paid.' I'll have a clear conscience."

In his will he left the old home and land to the town of Warren for a children's play. ground, which was the first bequest of its kind, so far as is known, in this part of the country; to the Library Association, his books and some of the curios he had collected in the Orient, also his decoration from the Emperor of Japan, which he valued the most of all his many gifts that he received while professor in the Agricultural College at Sapporo, Japan.

His surgical instruments and his microscope were left to the City Hospital, Boston, Massachusetts. A sum of money, 1000 Japanese silver yens, equivalent to $\$ 500$, was given to the college at Sapporo, Japan, for a drinking fountain, suitably, inscribed, to be placed on the college grounds; the income of $\$ 1000$ to the Agricultural College in Amherst, Massachusetts, to purchase books on hygiene.

'To the Loyal Legion, Boston-curios of John Brown times.

After a few other bequests to relatives and friends, the residue of the estate was left to Harvard Medical School.

The remarkable scope of the testator's ideas is shown in the use assigned to the income of the property. It is a fund for maintaining a Cutter Lectureship on Preventive Medicine, one of the first bequests for such a purpose; these lectures to be free to all medical men, and to representatives of the press.

As specified in the will, the following inscription has been chiseled on the family monument in Pine Grove Cemetery, Warren, Massachu. setts.

\section{"John Clarence Cutper, B.Sc., M.D. Meiji IV Japan July 10, 1851 February 2, 1909',}

In closing this sketch of Dr. Cutter's life, there are two incidents which may reveal a little of his character.

As he was consulting physician and surgeon to the Imperial Government, he was not allowed to take fees, but could accept presents, and many of his rare curios were gifts from grateful patients. One of these is a rare specimen of ancient porcelain, which the owner, an old man, gave as the most valued of all his possessions. A bit of amusing history is connected with this gift. The old man had a young wife, who, as the doctor thought, preferred to have her spouse called to a higher life. The doctor set himself 
to work to cure the old man who was so pleased that he gave him the ancient porcelain. While in Japan, the railroad from Otaru to Sapporo was built. Soon after it was completed, the doctor had occasion to take the train to go to a town, a short distance down the line. When out a few miles, the engine jumped the track. The Japanese did not know what to do. The doctor, who watched them in their efforts, finally asked for jack-screws and described them. They were found, and with his assistance, and directions to the Japanese, the engine was back on the track. They looked at him in amazement, and asked, "Do all the men in America know how to do everything?" He told them that most boys where he lived were taught many things, but not everything. The engine was very small compared with those in this country even at that time.

But the incident illustrates the resourcefulness of the man, which helped to win for him the admiration and confidence of those about him.

\section{UIliniral Zlepartment.}

\section{SYPHILIS OF THE LUNGS.*}

By Nathaniel K. Wood, M.D., Boston.

THE finding of extensive dulness of the lungs during routine examinations in cases that did not show tubercle bacilli in the sputum has interested me to collect data that would point to some other cause than tuberculosis for such dulness.

At the same time the recognition of the Spirocheta pallida and the discovery of the Wassermann test have proved pathological findings, not heretofore recognized as such, a manifestation of syphilis. A striking example of what I mean is aortitis. Therefore, the question suggests itself. can the prevalence of lung dulness be correlated with the prevalence of syphilis? Can sufficient evidence be found' clinically to justify a diagnosis of syphilis of the lungs? Is that evidence of sufficient weight to convince the pathologist that he is overlooking something, or calling something already seen by a wrong name?

From twenty-two cases, I have selected a series with histories suggestive of syphilis, whose physical examination showed definite lung impairment. If the Wassermann test proved positive, I had sputum examinations made and von Pirquet tests tried. If these proved negative, I had radiographs taken of the chest and long bones of the lower leg. I was able to select seven cases that showed definite histories, definite lung impairment, positive Wassermanns, negative sputum and von Pirquet tests. To these were added four cases which did not meet the

* Read before the American Climatological and Clinical Association at Washington, D. C., May 11, 1016. above requirements. One had a few tubercle bacilli in the sputum, Gaffky No. 2, but had in addition a markedly positive Wassermann test and definite radiographic findings. The three others were children, upon whom the diagnosis of tuberculosis had been made and who had been carefully treated for tuberculosis several years. Repeated examinations of their sputum have shown no tubercle bacilli, but their family histories were strongly suggestive of syphilis. No Wassermann tests or radiographs were made upon them, but I wish to eite them because of the marked effect which mixed treatment had upon them.

Case 1. W. J., Male. January 29, 1915.

F. $H$. Could not be obtained.

P. H. Gonorrhea twice. Hard chancre.

$P$. $I$. Pains in abdomen. Cough and expectoration. Constipation.

P. E. W. d. \& n. Skin negative. M.M. pale. Teeth bad. General glandular enlargement.

Lungs. Marked dulness in upper 2/3 and moderate dulness lower third, in front. Rare crackles left top. In back, few medium crackles above the spine scapula. Harsh respiration from the apex to the angle of scapula. Right back, diminished respiration upper half with few dry râles. Fairly good respiration lower half.

Heart. Not enlarged. Action regular. First sounds weak. No murmurs. $\mathrm{P}^{2}$ plus.

Liver. Edge felt $1 \frac{1}{2} \mathrm{~cm}$. below costal margin.

Old scar of the penis.

Sputum. Negative.

Von Pirquet. Negative.

Wassermann. Positive.

Radiographic Findings. Clavicles, lower ribs and tibiae show periosteitis and endosteitis.

Chest. Aortitis. Infiltration lower third right lung.

Weight. 125 pounds.

Treatment. Tr. nux and gentian before meals. Mercury and potassium iodide after meals.

July 31,1915 . Has had a good month. No pain in abdomen for six weeks. No cough. Bowels move well. Eats and sleeps well.

Weight. $1321 / 2$ pounds.

Lungs. Dulness in front remains the same. Respiration distinct. Fair excursion. Rare dry râles at apex left side. In back, dulness has decreased on the right side. Respiration is heard easily, excursion good, no râles. On left, broncho-vesicular upper half. Good lower half. Few dry râles, upper half.

February, 1916. Has improved since laste note. Weight, 135.

Case 2. C. M., female, 55 years old. Single. March 19, 1915.

$F$. $H$. Father and mother died when she was very young. Six brothers or sisters died before one year old.

$P$. $H$. Heart and kidney trouble 7 years.

$P$. I. Loss of appetite and strength, pains in joints, headaches, constipation, chronic cough with expectoration and shortness of breath. Poor memory.

P. E. W. D., p. n. Skin pale. M. M. pale. Teeth poor. General glandular enlargement. Chest small and flat. Clavicles and ribs prominent.

Lungs. Marked dulness both lungs throughout, 